\title{
Interpretation of democracy, pluralism and tolerance among the young activists of Muhammadiyah and Nahdlatul Ulama
}

\section{Interpretasi demokrasi, pluralisme, dan toleransi di kalangan aktivis muda Muhammadiyah dan Nahdlatul Ulama}

\author{
$\underline{\text { Ali Maksum }}^{1}$, Priyono Tri Febrianto ${ }^{2}$, \& Esa Nur Wahyuni ${ }^{3}$ \\ ${ }^{1}$ Department of Government, Faculty of Social and Political Sciences, Universitas Brawijaya \\ ${ }^{2}$ Department Elementary Education, Faculty of Education, Universitas Trunojoyo \\ ${ }^{3}$ Faculty of Tarbiya and Teacher Training, UIN Maulana Malik Ibrahim \\ Address: ${ }^{1}$ JalanVeteran, Malang, East Java 65145 \\ ${ }^{2}$ Jalan Raya Telang, Bangkalan, East Java 69162 \\ ${ }^{3} J a l a n$ Gajayana No.50, Malang, East Java 65144 \\ E-mail: alimaksum@ub.ac.id, priyono.febrianto@trunojoyo.ac.id,\& esanw@uin-malang.ac.id
}

\begin{abstract}
Anarchism and other forms of violence committed by religious groups and mass organizations are still very common in Indonesia. There have been violations of human rights, religious freedom and civil liberties, which are essential pillars of democracy. Indonesia, as a country that adheres to religious freedom regards all forms of intolerance as violations of democracy. This study described and explored the views of young cadres of Muhammadiyah and Nahdlatul Ulama (NU) in Malang, East Java, about democracy, pluralism and tolerance. This research intended to unravel some of the issues of how young generations of Muhammadiyah and NU understand democracy, pluralism and tolerance and if their views are associated with their social construction. This study employed qualitative methods using interviews and direct observations to collect the data. The results of this study showed there were differences in the patterns between the younger generation and the older generation of Muhammadiyah. The members of Muhammadiyah recognized that the young cadres of Muhammadiyah tended to act more violently towards intolerant mass organizations compared to their senior (old cadre) generation. The senior cadres, such as the Muhammadiyah Youth, were more likely to be calm when responding to the presence of radical organizations. The senior cadres of Muhammadiyah tended to be openminded with the community organizations that are perceived by the public to be a radical mass organization, which is fundamental in addressing the presence of radical organizations. This view indicated by the absence sense of precariousness or a situation that is considered to be very threatening to religious and national life while still in the corridor of diversity. On the other hand, the younger generation of Nahdlatul Ulama showed a different pattern, revealing that their seniors tended to be harsher in responding to radical organizations and supporting mass organizations.
\end{abstract}

Keywords: democracy; pluralism; tolerance; Muhammadiyah; Nahdlatul Ulama

\begin{abstract}
Abstrak
Anarkisme dan bentuk-bentuk kekerasan lain yang dilakukan oleh kelompok agama dan organisasi massa masih sangat umum di Indonesia. Jelas bahwa telah terjadi pelanggaran hak asasi manusia, kebebasan beragama, dan kebebasan sipil yang merupakan pilar penting demokrasi. Indonesia, sebagai negara yang menganut kebebasan beragama, menganggap semua bentuk intoleransi adalah pelanggaran dalam demokrasi. Studi ini menggambarkan dan mengeksplorasi pandangan para kader muda Muhammadiyah dan Nahdlatul Ulama (NU) di Malang, Jawa Timur, tentang demokrasi, pluralisme, dan toleransi. Penelitian ini dimaksudkan untuk mengungkap beberapa masalah bagaimana generasi muda Muhammadiyah dan NU memahami demokrasi, pluralisme dan toleransi dan pandangan mereka jika dikaitkan dengan konstruksi sosial mereka. Penelitian ini menggunakan metode kualitatif dengan menggunakan wawancara dan observasi langsung untuk mengumpulkan data. Hasil penelitian ini menunjukkan ada perbedaan pola antara generasi muda dan generasi tua Muhammadiyah. Anggota Muhammadiyah mengakui bahwa kader muda Muhammadiyah cenderung bertindak lebih keras terhadap organisasi massa yang tidak toleran dibandingkan dengan generasi senior mereka (kader lama). Sementara kader senior, seperti Pemuda Muhammadiyah, lebih cenderung tenang dalam menanggapi kehadiran dan organisasi radikal. Para kader senior Muhammadiyah memiliki kecenderungan untuk berpikiran terbuka dengan organisasi masyarakat yang dianggap oleh publik sebagai organisasi massa
\end{abstract}


radikal, dan mendasar dalam menyikapi keberadaan organisasi radikal. Pandangan ini ditunjukkan dengan tidak adanya rasa genting atau situasi yang dianggap sangat mengancam kehidupan beragama dan nasional sementara masih dalam koridor keberagaman. Di sisi lain, generasi muda Nahdlatul Ulama menunjukkan pola yang berbeda, mengungkapkan bahwa senior mereka cenderung lebih keras dalam menanggapi organisasi radikal dan organisasi massa fundamental.

Kata kunci: demokrasi; pluralisme; toleransi; Muhammadiyah; Nahdlatul Ulama

\section{Introduction}

Some of the essential themes recently discussed by Muslim scientists and religious organizations in Indonesia are a democracy, pluralism, and tolerance (Kurzman 2003:133-158). These discourses rise along with the Reformation Era and its increasing demand for freedom in various areas of life, including politics and religions. Reformation has given rise to various opportunities and challenges. In terms of Islam, the opportunity came in the form of increasing various Islamic 'da'wah, while the challenge faced was the emerging religious schools that speak out in conflict with Islamic faith (Sopyan 2015:204). The discourse of democracy, pluralism, and tolerance is generally associated with the context of interfaith relations. These themes discussed not only based on the reality of a pluralistic society consisting of various tribes and religions but more importantly, to build a link between diversities in the bonds of civilization. Therefore, pluralism and tolerance are needed to assure the safety of humankind, which can be carried out through monitoring and balancing mechanisms among groups in society (Rachman 2001).

The Reformation Era, marked by the end of the New Order with the resignation of Soeharto from his position as president on May 21, 1998, brought a significant influence in the Indonesian political arena. It admitted that New Order had a considerable influence in the form of political commodities carried out by the elites as development tools (Anshori 2008:7). On the other hand, the Reformation Era, from the experts' point of view, is considered to have changed the basis and the latest political constellation in Indonesia (Emerson 2002).

Three significant events mark the end of the New Order and the reign of the Reformation Era. First, the collapse of 'Golkar's political hegemony, which was supported by the bureaucracy and the military as the primary buffer of the New Order. On the one hand, government administrators during the New Order were almost entirely under the control of the president. On the other hand, there were no political forces capable of balancing 'Soeharto's power and 'Golkar's political apparatus (Amir 2003:1). This political power experienced suppression by several parties, including political figures and community movements to overthrow Suharto (Ancient 2009:16). The end of the New Order led Indonesia to find its way out of an authoritarian government towards a democratic system in open society (Republika 1998). After the fall of the New Order, the government was handed over to B.J. Habibie, and an engineer turned into a politician, who then encouraged the Indonesian government to establish democratic elections in 1999 (Sulistyo 2002:78).

Second, the birth of a multi-party political system that provides opportunities for each political group with different ideologies and aspirations to participate in enlivening the national political stage. The multi-party system also based on the complexity of highly heterogeneous and pluralistic society such as Indonesia (Saraswati 2012:137). This phenomenon was evidenced by the emergence of a number of diverse Islam-based political parties, such as Partai Kebangkitan Bangsa (PKB), which was established by a number of influential Kiai in Nahdlatul Ulama (NU), Partai Amanat Nasional (PAN) that was founded by Muhammadiyah activists, and other Islam-based parties such as Partai Bulan Bintang (PBB), Partai Persatuan Pembangunan (PPP), and Partai Keadilan Sejahtera (PKS) (Amir 2003). These parties have many constituents and represent remarkable strength in post-New Order politics (Al-Hamdi 2017:50).

Third, the emergence of various religious groups outside Indonesia's Islam-based political organization, namely Muhammadiyah and Nahdlatul Ulama (NU). Religious organizations born in 
the Reformation era were generally radical, such as Laskar Jihad, Majelis Mujahiddin Indonesia (MMI), Front Pembela Islam (FPI), and Hizbut Tahrir Indonesia (HTI) (Jahroni 2004). The emergence of these radical movements was an effect of the new open democracy (Rokhmad 2012:80).

The change resulting from religious contestation above, primarily the result of the third cause, is the increasing variety of expressions that mark the rise of the Islamic movement in Indonesia, along with the freedom movement in the Reformation Era amid the ongoing political constellation. The Reformation Era marked by a political Islamic revivalism movement in which there was a religious, social movement. This condition has resulted in the rise of Islamic political ideas to establish a sharia state, bringing about ratifications of approximately 60 regional regulations that were inspired by Islamic political ideology (Nubowo 2015:61).

The implications of emergence radical and moderate religious movements above are as follow: First is the emergence of a movement that desires the union between Islam and the state. The movement is increasingly intense and continues to reject the democratic system and strive to formally implement Islamic law as the basis and customary law of the state. They are known as radical Islamic groups, with their main agenda being to formalize of Islamic law in the state. As a substitute for the democratic system, these groups discuss the realization of Negara Islam Indonesia (NII), Darul Islam (DI), Daulah Islamiyah, Khilafah Islamiyah, and Emir Islam Indonesia (Maksum 2017:405). The development of conservative Islamic ideas supported by freedom of speech, especially related to the rules of public life, including regulating the values of social and moral relations (Brenner 2011).

Second is the movement that requires the enactment of Islam in public life (including politicalstate), which is not as formalistic as desired by the first group. This movement is more an antithesis of radicalism and religious formalism and desires for inclusivism in the life of the state. These second groups demand that even if Islamic law pertains in public life, the implication must cover the essential spirit of Islam such as justice, morality, equality, prosperity, tolerance, and human rights. They are better known as moderate Islamic groups. These moderate Islamic groups affiliated with two large organizations, namely Muhammadiyah and NU (Ummah 2012:117); the development of this significant Islamic movement has expanded since 1980, along with the times of Masyumi Islamic party, and reached its peak of democratic freedom after the collapse of New Order (Bruinessen 2002:123).

Indonesia, as the largest Muslim country, according to some political observers, has not been entirely prosperous in practising democracy. According to Roy (1994), Indonesia is facing cynical views towards the existence and articulation of "political Islam" in the Muslim hemisphere. In its history, according to him, politically oriented Islamic activities - in short, "political Islam" - have failed to offer a model of Muslim democracy. The political victory of Islamists in Muslim countries only brought a variety of superficial changes in the field of law and customs. Islamism later turned into a type of neo-fundamentalism that only focused on the movement to uphold the sharia without creating new political forms (Roy 1994). It also supported by the fact that the 2009 and 2014 elections depicted the decline of Islamic political parties that could not gain many votes, while parties from nationalist circles gained far more votes. This situation strongly influenced by the power of Nahdlatul Ulama and Muhammadiyah as well as resistance from non-Muslim Indonesian groups (Ahnaf 2016:128). Islamic governance is considered to have a weakness in the form of not being able to separate the secular and the religious, making it difficult for countries with Islamic political style to implement governance like their Western counterparts (Lipset 1990).

Vedi R. Hadiz states that Muslim-dominated democratic country like Indonesia is "illiberal democracy", a type of disguised democracy (Hadiz 2004:55-71). According to 'Hadiz's observations in several major cities in Indonesia, such as Yogyakarta and Medan, during general elections, there is a boom in vote-buying and money politics, as well as coalitions between political thugs and capital owners. This phenomenon, according to Hadiz, is not a characteristic of liberal democracy but is a deviation and even a crime against democracy (Hadiz 2003:607). Money politics indicates that the critical element of electoral mobilization is done through money, which is most commonly found in third-wave democracies (Muhtadi 2013:41). The phenomenon of money politics in Indonesia is 
evident in the political transition during the 1999 election which increased voter atomization, the high fluidity of political affiliation, and the increasing dominance of professional political strata (Aspinall 2005:120). On the other hand, Frederic Volpi argues that the phenomenon of democracy in the Muslim world is pseudo-democracy, "a political order that tries to resemble liberal democracy, but is a false democracy" (Volpi 2004:1061-1078). According to Volpi, democracy is only used for the sake of power, not for building and realizing justice and 'people's welfare. The political chaos and bloodshed also cause arguments for rejection of the Islamic political system, or the socalled Khilafah happened during the assassination of Khulafaur Rasyidin and the discriminatory treatment of non-Muslims and women (Adhayanto 2011:90). Islamic government or Khilafah is also not following democratic government with its openness. It is an authoritarian regime that gives full legitimacy to the government to run politics by seeking economic stability of a country (Fish 2002:8).

Indonesia has not entirely been able to implement a real democracy. Democracy, as a system of tolerance in the life of the nation and society, is still far from being realized. Several incidents of violence in the name of religion are still prevalent. The attack of Front Pembela Islam (FPI) on the event organized by the AKKBB (Alliance for Freedom of Religion and Belief) at Tugu Monas (June 1, 2008), another FPI attack on the Ahmadiyya Community in Cikeusik, the attack of radical Salafi group against the Shi'a in Bangil, another attack on Shi'a groups in Sampang, and more recent incidents, including the bombings of several churches in Surabaya, the dissolution of Felix Siauw's recitation by members of Banser, the dissolution of Ustadz Abdussomad recitation in several places, and other similar events. The attacks and dissolution carried out by Islamic organizations against other Islamic organizations have made Islamic organizations become "pressure groups" for one another (Pertiwi 2015:18).

Meanwhile, the bombings in various cities in Indonesia could not be separated from the influence of transnational Islamic networks in the Middle East. This network also spreads propaganda so that they can carry out violent actions they call jihad (Lym 2005:13). Incidents above show that the values of democracy, pluralism, and tolerance still cannot be accepted by some Muslim communities. All forms of violence and anarchies carried out by religious organizations above show that tolerance is a critical point. Cases of violence that brought to court are being discharged by releasing the perpetrators from punishment because of their affiliation to particular religious groups (Muttaqien 2014:2). These intolerant incidents have violated religious freedom and human rights - the essential pillars of democracy (Rachman 2010). Violence in the name of religion is more common than violence due to institutional strength, and this type of violence causes more deaths than violence perpetrated by secular terrorist groups (Silberman et al. 2005:764).

Based on the discussion above, this study answers the urgency by describing the response of young activists of major Islamic organizations in Indonesia, namely Muhammadiyah and NU, to the concepts of democracy, pluralism, and tolerance in Malang. Both organizations are moderate and mainstream and have coloured religious social and political life in Malang. This study employs democratic theory, pluralism theory, and tolerance theory to analyze the data. In terms of democracy, this study defines it into two: procedural democracy and substantive democracy. Procedural democracy, as explained by Joseph A. Schumpeter, is an "institutional agreement to achieve political decisions in which individuals gain the power to make decisions through a competitive struggle that represents the voice of the people" (Schumpeter 1947:269). Procedural democracy includes political parties, general elections, and representative institutions. Substantive democracy, complementarily, is related to the values of democracy carried out by community members in daily life.

Though there is no agreement among political experts of the theory of democracy regarding what elements must be included in democratic values, this study adheres to the followings. Stace says that democratic values include secularism, liberty, and individualism (Stace 1950:37). According to Roshwald (2000), democracy contains essential elements, such as freedom, independence, justice, and equality (in Fachruddin 2006:28). Daniel Sparringa, alternatively, includes two spirits in democracy, namely tolerance (respect for diversity) and pluralism (recognition of the diversity of ideas and political and ideological beliefs) (Sparringa 2006). 
The concept of religious pluralism is to make tolerance as a way of life in order to maintain harmony between people of different religious groups. If pluralism emphasizes more on recognizing the existence of differences and willingness to acknowledge the truth of other religions, tolerance emphasizes the attitude of mutual respect among people of various religions to create harmonious customs and social arrangements between them in daily social life.

Tolerance means the willingness or ability to tolerate someone or something. The word tolerate means: 1) allow (something that is disliked or disagreed with) without interfering; 2 ) endure (somebody or something) without protesting (Hornby 1989:1350). Whereas in terms of theology, Islam teaches tolerance in religious life. Islam teaches that people should always communicate or have dialogues between people of different religions. Prompts for interreligious dialogue are embedded in Islamic teachings and must be put forward when dealing with adherents of Judaism and Christianity. "AlQur'an 'Al-'Ankabut [29]: 46: "And do not argue with the People of the Book, unless in the best way."

According to Abdillah, such tolerance only applies to sociological and not theological issues. Sociological issues deal with social problems of society, while theological questions involve beliefs. Therefore, Muslims can cooperate with people of other religions to solve secular affairs, but not in terms of religious affairs (Abdillah 1999:154). In the effort of building awareness of tolerance among people of various religions, two approaches can be taken. First is an approach that emphasizes the principle of co-existence an approach that recognizes religious differences. Second is an approach that emphasizes the principle of pro-existence, the existence of shared problems that need to be resolved by people of different religions.

The pro-existence approach is characterized not only by the presence of peaceful co-existence but also by awareness to be part of the effort to solve problems faced by other groups. Therefore, pre-existence requires an end to indifference and ignorance of the wellbeing of other groups. In other words, pro-existence requires the principle of inclusion, not exclusion. This kind of quality is needed to enable different groups to need to produce integration in addition to the versatile local and particular identity. A pro-existence approach must always accompany the co-existence approach. (Sparringa 2006:22-23).

This research aims to analyze tolerance among religious people. Religious tolerance means allowing and appreciating those of different religions, beliefs, and religious understandings to live together in society. Religious tolerance, thus, means a set of values or manners that direct human behaviour in order to respect other people with different religions. In responding to the reality of pluralism and the emergence of different Islamic movements in Malang, such as Hizbut Tahrir Indonesia (HTI) and Salafi, Muhammadiyah and NU youth organizations often have different opinions. Muhammadiyah is more accommodating and tolerant, while Banser and Ansor often conduct sweeping, encouraging hate speech and persecution to HTI and Salafi organizations. Therefore, comparing the responses of the members of the two major Islamic organizations is deemed necessary.

The study categorizes them into several major issues. First is on how young generations of Muhammadiyah and NU young understand democracy, pluralism, and tolerance. Second is the view of young generations when it is associated with their social construction. By answering these two questions, the researcher aims to explore the understanding of young members of Muhammadiyah and NU regarding democracy, pluralism, and tolerance. Moreover, the researchers try to understand their views based on their social construction and the factors that determine their thinking.

\section{Research Method}

Looking at the problems highlighted above, it is clear that the research questions are more related to understanding (meaning). Therefore, this study designed with a qualitative approach. Qualitative research can be understood as a research procedure that produces descriptive data in the form of words and notes relating to understanding, meaning, and value (Kaelan 2005:5). Qualitative research paradigm uses an inductive thinking framework. In this case, the abstraction compiled by the 
researchers based on the collected data to be further grouped. In terms of application, the qualitative method in social sciences research is carried out with steps to formulate problems, collect data in the field, analyze data, formulate research results, and prepare recommendations (Danim 2002:51).

The informants in this study were obtained using snowball sampling. Informants eligible for this study were either administrators, activists, or followers of Muhammadiyah or Nahdlatul Ulama organization. The young cadres were those aged 20-40 years, while older generations were those aged over 40 years. The number of informants in this study was 16 people, consisting of four Muhammadiyah young cadres, four Muhammadiyah old cadres, four Nahdlatul Ulama young cadres and four Nahdlatul Ulama old cadres.

\section{Results and Discussion}

\section{Interpretation of democracy, pluralism, and tolerance}

According to some political experts, Indonesia, as the largest Muslim country, has not been entirely successful in practising democracy. The political victory of Islamists in Muslim countries, in fact, only brings a variety of superficial changes in the fields of law and customs. Islamism later turns into a type of neo-fundamentalism that only focuses on the movement to uphold sharia without developing new political forms. Neo-fundamentalism is a political phenomenon which considered quite dangerous because it encourages an inferior direction of intellectuality because of literal and textual views that do not give appreciation to classical Islamic heritage that is full of alternative thoughts (Zuhdi 2010:85). Frederic Volpi sees the phenomenon of democracy in the Muslim world as pseudo-democracy, namely "a political order that tries to resemble liberal democracy without a real effort to become a liberal democracy". This understanding of fundamentalism leads to opposition to constitutionalism and rejects secularization so that Islamic political groups are difficult in efforts to uphold Islamic law including in law and economics (Sephard 1987).

Volpi argues that democracy in Muslim countries is only used for the sake of power since the ruling government could not gain much power if they are too democratic. On the other hand, Vedi R. Hadiz calls Muslim democracy, like the one in Indonesia, as illiberal democracy, a kind of undercover democracy. Hadiz, based on the observations he made in Yogyakarta and Medan, reports that during the general elections, there were money politics, vote-buying, as well as coalitions between the political mafia and capital owners. They were not typical of liberal democracy, but the basis of something else - a type of non-liberal democracy that is controlled by money, politics, and crime which is already established, and can found anywhere.

The claim that Indonesia has not implemented democracy turns out to receive mixed responses from informants in this study. Informants from Muhammadiyah and NU had different views about democracy itself. In the democratic scheme, Muhammadiyah young cadres saw Pancasila Democracy as the ideal system and capable of accommodating differences. This argument is in line with Dewantara (2017:22), as he states that a democratic system believed by a society is an original condition, enriching emancipatory discourses, and constituents that are subject to humanitarian values and peace. It indicates that democracy is a rich, plural, and meaningful space of life. Democracy based on the general premise that all human beings in a country are equal without the need to distinguish religion, race, or class. Likewise, Pancasila is a form of negotiation between the interests of nationalist and religious groups in which it calls for respect for differences between people (Mutaqin 2016:178). Accepting reality is a necessity in a democracy. In other words, democracy can be described as a system for managing differences, where the differences arranged in rules agreed upon by different groups. In addition, Schmitter (1991) asserts that democracy encourages governments to be responsible for their practices and actions. Therefore, in certain conditions and based on humanitarian needs with free will and the spirit of freedom, democracy chosen as a way of independence. A study conducted by Lubis (2009) also states that a democratic system enables people to participate in government, and the created regulations become the basic principle to establish a fair democracy. 
In the context of a democratic country, even though the rules agreed upon together are not too sacred as many fatwa and legal decisions pertained in a particular religion, the rules must be respected by all parties together and accompanied by opportunities to express opinions (Civil-Political Rights). As quoted by Poti (2011:18), Theodorson (1969) states that democratization is closely related to the freedom to obtain the rights and benefits of human rights, including freedom of communication and expression. That is, unlike orders in religion, rules in a democratic system can be changed and amended with mechanisms agreed upon together. This finding is in line with a study conducted by Bollen (1990:10), which finds that every individual in a democratic country has the freedom to express political opinions in any media, and freedom to form or join any political group. The foundation of democracy is a substance that formulated the people for the people of the world and is relative, temporary, and limited. With this relatively essential character of democracy, the potential for horizontal conflict with religious belief (the dogmatic character of religion) refers to absolute truth.

\section{Interpretation of democracy by Muhammadiyah}

Muhammadiyah, as an Islamic movement, has the following vision:

"As an Islamic movement based on the Qur'an and the As-Sunnah with the character of tajdid, always Istiqomah and active in carrying out the Islamic preaching with the spirit of amal ma'ruf nahi munkar in all areas in the effort to bring about Islam that is a blessing to the creation or existence of a true Islamic society".

However, in practice and historical experience, Muhammadiyah can go hand in hand with the democratic system. There are similarities in the teachings of Islam and democracy: that all humans are equal. This opinion is in line with the concept of the pillar the rule of law, according to Jimly Asshiddiqie. As quoted by Khairazi (2015:72), everyone is equal before the law and government; therefore, discriminatory actions prohibited. The results of the research also reinforce this opinion by the professor of cultural anthropology of Kangwon National University, South Korea, Kim Hyung Jun, who states that the tradition of democracy has lived within the Muhammadiyah organization. First, the process of electing the General Chairman of Muhammadiyah has taken place democratically. A democratic election is in line with the findings of Matolino (2009:37), which states that humans can solve differences through consensus achieved through logical dialogue and persuasion both by the opinion of the majority and representing the will of the minority. Secondly, internal democratic life in Muhammadiyah has become a common practice. It can be seen from the habit of conducting open and polite discussions, debating issues based on rationality, being able to respect the opinions of others, not alienating and opposing those who have different opinions, and accepting what has been decided by the deliberation forum. Democratic life reflected in Habermas's theory of public space, where open discussions about public interests are freely accessible (Aminah 2007:8). The open discussion also aims to reach decisions and become a process in which initial preferences are changed to take into account the views of others (Miller 1992:57).

\section{Interpretation of democracy by Nahdlatul Ulama}

Nahdlatul Ulama is one of the organizations with strong nationalism in its ideology. In the formulation of the 1945 Jakarta Charter, one of the NU leaders, Wachid Hasjim, became a member of the small committee to formulate the foundation of the state (Haidar 1994:7). In its long history, Nahdlatul Ulama has shown a considerable contribution to this nation. NU noted as a religious organization that participated in the G30S / PKI crackdown through Ansor (Nahdlatul Ulama youth organization) to destroy PKI (McGregor 2009:199). The organization is still consistently showing its contribution to the nation. It is different from Muhammadiyah, which is careful to enter the national conflict. Nahdlatul Ulama consistently shows its alignments firmly.

Besides, NU's partisanship in the state is evident from the intimacy built with the military. After the G30S / PKI incident, the relationship between NU and the military became increasingly close to the common interest, and the two participated in safeguarding the state's conduciveness from communism 
at the time (McGregor 2009). Compared to Muhammadiyah, NU has a much more intimate relationship with the military, as evidenced by the annual agenda of shalawat recitation that involves Kyai and military members in Anwarul Huda Islamic boarding school in Malang. This intimacy makes NU a long military hand in the process of safeguarding political conduciveness in Malang, particularly in matters of tolerance and diversity. Banser, as NU semi-military organization, has carried out dozens of sweeping against the agenda of radical organizations in Malang. A study conducted by Wardani (2019:303) also found the role of Banser in preventing the spread of radicalism through Islamic studies in Sidoarjo which were considered unable to appreciate differences in society. Banser was also noted in the study of Susilowati et al. (2019:60), which found that the organization's members burnt flags with the words tawhid in Sukabumi in 2018 to reject the notion of radicalism which had infiltrated through the ideology of tawhid. The basis of Nahdlatul Ulama in Malang is quite strong as seen from various cultural agenda of Nahdlatul Ulama, such as Jam' iyah Sholawat Wal Maulid and monthly recitation agenda. The above agendas become one of the instruments for NU's ideology distribution in Malang. Nur (2018) in his study, found that in Lampung, shalawat recitation agenda is used as a tool to revitalize the values and traditions of Nahdliyin or NU followers. The strength of NU base is also seen from thousands of worshipers. Interestingly, the recitation agenda is one of the most frequently used methods as an ideological distribution and disagreement with other groups.

\section{Attitudes towards pluralism}

As revealed in the background, Muhammadiyah and Nahdlatul Ulama (NU) initiated the birth of religious groups outside Indonesian Islam. This movement followed by the foundation of organizations with liberal ideals such as JIL, and radical ones such as Lasykar Jihad, Majelis Mujahiddin Indonesia (MMI), Front Pembela Islam (FPI), and Hizbut Tahrir Indonesia (HTI).

The rise of the Islamic movement can be seen from the increasing interest of many urban residents to study religion (Ratnasari 2010). Sakai \& Fauzia (2013) stated that the public interest in studying religion had increased since 2002, and this supported by various factors such as television shows in the form of religious lectures and recitation groups. Another implication is the emergence of two main currents which are considered to intersect with each other. However, the development of pluralism is not present in peace without significant conflict. The contestation of national conflicts relating to pluralism also dramatically affects the views of retainers of moderate organizations in Malang in interpreting pluralism.

\section{Attitudes of Muhammadiyah cadres towards pluralism}

Plurality is essential to the young cadres of Muhammadiyah. However, the meaning of pluralism is perceived and understood differently. Pluralism is not limited to being understood sporadically as a notion that teaches all religions are similar. As a major religious organization in Indonesia, Muhammadiyah believes that plurality does not only teach the ordinances of worship, but also teaches social relations between people, and invites Muslim to compete in doing good deeds (Zain 2007:113). This attitude of understanding plurality refers to senior members of Muhammadiyah who highly uphold pluralism, including Ahmad Syafi'i Ma'arif, Amin Abdullah, and Abdul Munir Mulkhan (Biyanto 2009:315). However, the meaning of "similar" relates to all religions which teach about the doctrine of the truth, namely the path to God.

Referring to the acute condition and disputes about the meaning of pluralism, there is a gap in the Indonesian society that results in rejection with excessive violence, which can lead to persecution. The claim about the religion they embrace as the most authentic religion, while the other is not true often causes intolerance issues. For young Muhammadiyah cadres, the claim is thought to be "fair" as part of the consequences of a choice towards religion. For Muhammadiyah, this large organization plays a crucial role in facilitating an era of transition that is peaceful, sustainable and democratic and believes that accepting plurality will bring benefits that are directed towards the goodness of many people (Barton 2014:289). 
Putting the rationalization of choice with a dialogical pathway for young Muhammadiyah cadres is considered the most moderate lane. Therefore, the false "claim" of true religion often hurts some Muslims, or the claim would be a great product of legitimacy and seems to be an authentic group of the teachings of Islam.

\section{Attitudes of Nahdlatul Ulama cadres towards pluralism}

Pluralism is also one of the critical discourses for Nahdlatul Ulama. It is revealed from the meaning of pluralism is very emphasized in the process of caderisation in the organization. Pluralism may give rise to the possibility of conflict. Conflict and plurality are closely related to modernization and are often motivated by differences between societies (Morrison \& Stevenson 1972). Several differences will create friction which eventually becomes the seeds of conflict, both in the discourse area and in the praxis region. In the context of Malang, the intertwined conflicts are still within the same period as political contestation in the city. National issues are still the cause of conflict. Indonesia, as the country with the largest Muslim population in the world, often faces a tension between liberal Islam and radical Islam. Khan (2003:417) asserted that liberal Islamic groups try to fight radical groups through a strategy of promoting their ideology and using alternative interpretations of Muslim reality and a vision in which all Muslims can find hope. In facing the reality of pluralism and the challenges of modernity, developing ideas such as democracy, secularism, liberalism and pluralism is undoubtedly fundamental. Secularism is vital because the benefit of the nation is more important than group interests, groups or ideologies of a particular religion. Developing the idea of liberalism is also essential because it recognizes the freedom and civil rights. With the existence of liberalism, the recognition of diversity and tolerance is as high as moral and cultural differences (Galston 1995:528). Freedom applies to all humanity, namely freedom and civil rights (civil rights, civil liberties): such as freedom of thought, opinion, religion, belief, etc. The idea of pluralism is also essential to be mainstreamed to face plurality, tolerance, openness and equality.

\section{Interpretation of tolerance}

Tolerance means the willingness or ability to tolerate someone or something. The word tolerates means: 1) allow (something that is disliked or disagrees with) without interfering; 2) endure (somebody or something) without protesting (Hornby 1989:1350). In the Great Dictionary of the Indonesian Language, tolerance (noun) has three meanings; 1) tolerant; 2) measure limits for additions or deductions that are still permitted; and 3) irregularities that are still acceptable in work measurement whereas the word "tolerant" (adjective) means being tolerant (appreciating, allowing) of own stand (opinions, views, beliefs, habits, behaviour, etc.) that are different or contrary to one's own stance. In addition to these two words, there are two other meanings related to tolerance, namely "tolerating" (verb) means being tolerant, and the word "tolerating" (verb) means silence, let.

Religious tolerance means allowing and appreciating those of different religions, beliefs, and religious understandings to live together in society. Religious tolerance, thus, means a set of values or manners that direct human behaviour in order to respect other people of different religions. Habermas (2004:13) noted that religious tolerance becomes a legal concept of a country that regulates the majority must behave tolerantly towards minorities. This study found fundamental differences in patterns regarding the tolerance response by Muhammadiyah and NU cadres, activists and young leaders. The differences are illustrated in Table 1.

\section{Interpretation of tolerance by Muhammadiyah}

As the largest Islamic mass organization in Indonesia, the existence of Muhammadiyah during the life of the nation and state is quite calculated. Moreover, Muhammadiyah has 30 million members. These 30 million members are very strategic; especially the organization has a long historical root of relations and politics have long historical roots.

However, this advantage does not necessarily make Muhammadiyah shine in political contestation. Muhammadiyah is more engaged in the field of public interest to support stable democracy through 
participatory culture (Mujani \& Liddle 2004:121). Muhammadiyah is one of the most conservative organizations in self-involvement in mass conflict areas, although Muhammadiyah had argued with Nahdlatul Ulama which destroyed various Muhammadiyah infrastructure in the past. Today's Muhammadiyah has stepped forward towards a new progression that has escaped the shadow of conflict. Muhammadiyah does not want to be bound in the realm of conflict between groups, both in state discourse and in religious discourse. It is evident in the reform era elections in 1999 that several Muhammadiyah figures involved themselves in political contestation by bringing the organization Partai Nasional Indonesia. However, the party's failure in elections illustrated that the Muhammadiyah mass base could not be fully used as a political tool (Jung 2014:77).

Table 1.

Various tolerance response patterns given by Muhammadiyah and NU cadres

\begin{tabular}{cl}
\hline \multicolumn{1}{c}{ Attitudes towards intolerance and radicalism } \\
\hline Nahdlatul \\
Ulama & $\begin{array}{l}\text { Republic of Indonesia based on Pancasila. Through a network spread throughout } \\
\text { Indonesia, and acting in various fields of service, becoming the front guard in pre- } \\
\text { venting and combating radicalism, terrorism and intolerance that threatens the joints } \\
\text { of the life of the nation and state. Second, cooperating with various parties that sup- } \\
\text { port the prevention of radicalism, terrorism and intolerance. On the contrary, it will } \\
\text { challenge parties with indication to support or allow the development of teachings } \\
\text { of radicalism, terrorism and intolerance. Third, inviting all components of the nation, } \\
\text { especially leaders of political parties and community leaders, not to politicize cases } \\
\text { of race, religion and ethic that can lead to hatred and intolerance in society. }\end{array}$ \\
$\begin{array}{l}\text { Avoiding any form of radicalism that leads to absolute understanding, especially } \\
\text { Muham- } \\
\text { containing extremism, intolerance and violence. However, do not be ambiguous } \\
\text { and politicize in constructing radicalism so that the label and concept of radicalism } \\
\text { is only intended for certain groups while negating other radicalism. }\end{array}$ \\
\hline
\end{tabular}

Muhammadiyah adheres to the principle of neutrality in politics. Although there are parties that are under the auspices of Muhammadiyah, the organization itself focuses more on promoting Islam with values, traditions, practices, and in some cases can support Islamic law (Freedman 2009:119). Muhammadiyah gives its members the freedom to choose any political movement that is consistent with their tendency. With around twenty million members, Muhammadiyah has refrained from direct involvement in politics, although many of its members are active in political parties (Woodward 2011:33). This principle was decided at the Congress in Surakarta in 1929 that "Muhammadiyah does not prioritize one of Indonesia's political parties and overestimate the other parties; in this case, Muhammadiyah respects these parties equally, but Muhammadiyah itself would prioritize participation in carrying out certain obligations to maintain the safety of Indonesian".

Unlike its old cadres, Muhammadiyah today still seems reluctant to be involved in the national political conflict, both cadres on a national scale and Malang cadres. Muhammadiyah cadres perceive that they should prioritize ummah rather than getting involved in the conflict. Itis due to the commitment of Muhammadiyah cadres to remain moderate and stand in the middle. Nevertheless, Muhammadiyah has never banned its cadres from engaging in practical politics nor supporting their cadres to take part in the political sphere. It is just that when it included in the political realm, then practical interests should not be brought into the body of the organization, and still uphold the morality following Muhammadiyah's frame.

By observing Muhammadiyah's style of movement regarding politics, Muhammadiyah cadres who are active in political parties are not permitted to involve political interests into the organization. Furthermore, the members must prioritize and defend Muhammadiyah regardless of political conflict or interest its members bring. For instance, the resignation of Prof. Amin Rais as Muhammadiyah chairman due to his involvement in PAN. Amin Rais left the Muhammadiyah leadership and joined practical politics by establishing PAN as a secular and explicit party designed to attract urban middle class and voters from various religious backgrounds (Mujani \& Liddle 2009:580). PAN's 
leadership was then led by Ahmad Syafi'i Ma'arif and did not make changes to the orientation of the organization in a frontal manner while maintaining neutrality and being critical of the government (Jurdi 2010:131). The alignment of each cadre in certain political tendencies is not permitted to associate with his identity as a Muhammadiyah cadre.

We recently still hear how some young Muhammadiyah cadres talk about politics by bringing their Muhammadiyah identity. For instance, Dahnil Ahzar Simanjuntak, the chairman of Muhammadiyah Youth, showed a critical opposition attitude towards Basuki Tjahaja Purnama (Ahok) including stating his readiness to commemorate the mass demonstration against Ahok (Hadiz 2018: 12). Dahnil appeared to be often present and talking about politics, and had been chosen as the spokesman for the presidential pair Prabowo-Sandiaga Uno. In addition, Dahnil serves as the President of the Tolerance Forum formed by President Jokowi.

Dahnil's attitude that represents Muhammadiyah youth encourages his fellow cadres to follow in his footsteps to be active in the issue of tolerance. It was conveyed by Adi Munazir, as he saw many Muhammadiyah cadres began to plunge and focus on the issue of tolerance. Adi interpreted this movement as to how the young cadres respond to derivative problems from tolerance. A study conducted by Saifullah (2016) on the organization of Muhammadiyah Student Association in Yogyakarta showed that young Muhammadiyah cadres are active in strengthening the unity among the well-organized Muhammadiyah youth. Therefore, it can be inferred that tolerance is a precarious nationality problem because tolerance has a significant effect on dehumanization spaces.

\section{Interpretation of tolerance by Nahdlatul Ulama}

Nahdlatul Ulama has become a pioneer as a face of tolerant Islam. The organization has undoubtedly maintained an atmosphere of tolerance in Indonesia. Kyai of Nahdlatul Ulama tries to introduce Islam with values that are taught through traditions developed in the community with conditions that do not conflict with Islamic law (Margono 2011:345). As an old Islamic organization in Indonesia, Nahdlatul Ulama has faced challenges, both in religious, national and community life. Even though extremist groups could not easily penetrate this organization, NU still faces infiltration from these groups (Wahid \& Taylor 2008: 37).

One of these challenges was revealed by the Head of PMII Malang, who stated a chronic problem of tolerance in the society. He reflected on how lately community tolerance has begun to erode. It can be seen from the chaos of national political contestations that have begun to hurt tolerance and diversity.

He further revealed that tolerance in NU is manifested in an inclusive attitude towards differences in views both in matters of religion, social issues and culture. Nahdlatul Ulama develops this inclusive attitude through Islamic education to deradicalize extreme understanding and maintain multiculturality (Muqoyyidin 2013). The estuary of tolerance is in the creation of intergroup understanding to have mutual enthusiasm to accept differences between pluralistic societies. This attitude of tolerance is also applied to the life of the nation and state.

For example, during the leadership of K. H. Abdurrahman Wahid or Gus Dur, the national figure emphasized that Indonesian people have the highest tolerance. Gus Dur taught open, liberal, inclusive thinking and emphasized pluralism that upholds tolerance in social relations (Barton 1997) to realize a peaceful nation's life. In addition, NU's contribution in caring for peace has indeed begun since the dialogue between K.H. Wahab and K.H. Sahal regarding fiqh that completed at an intellectual level. On the other hand, young NU cadres revealed a worrying situation regarding the chaotic atmosphere of today's tolerance, which resulted in the emergence of various new streams that threatened tolerance and diversity.

However, NU sees this as a challenge for young NU cadres to contribute to the nation and state. Ragil saw this situation as a form of opportunity for NU cadres to develop their knowledge in solving national problems. Ragil expressed his optimistic attitude as he argued that PMII cadres from small cities are more enthusiast facing tolerance problems. 


\section{Understanding of democracy, pluralism, and tolerance by young members of Muhammadiyah and Nahdlatul Ulama.}

There are significant differences in terms of pluralism principle between the two organizations. The young Muhammadiyah cadres, who asserted Muhammadiyah as a non-political organization, saw problems related to democracy, pluralism and tolerance as a humanitarian problem since many problems of intolerance and pluralism in Indonesia tend to lead to the process of dehumanization (strengthening the value of human rights). Therefore, young Muhammadiyah leaders are reluctant to take political steps and tend to separate this issue from political interests. Young Muhammadiyah leaders consider the issue of democracy, pluralism and tolerance to be solved if the space for perspective inclusiveness opened as widely as possible.

The way to respond to a radical movement as a utopian movement does not make Muhammadiyah young leaders feel threatened, as they see the emerging threat as a political threat that is not necessarily applicable in practical areas. The characteristics of Muhammadiyah as a missionary movement make Muhammadiyah leaders reluctant to comment on political elements in the problems. It tends to be different from the attitude taken by the young Nahdlatul Ulama cadres. The characteristics of Nahdlatul Ulama members who think of the whole supporting humanity factors, including political factors, make the young cadres have several views that tend to be political in this regard.

The influence of irresponsible political elites causes the tendency of attitudes taken by looking at the occurring phenomena of intolerance. Being Nahdlatul Ulama's young cadres make them tend to carry out prevention at the level of action, not only in intellectual dialogue such as young Muhammadiyah leaders. Although not as harsh as Banser, young NU leaders tend to show a cautionary attitude towards radical mass organizations.

Table 2.

Social attitudes towards democracy, pluralism, and tolerance

\begin{tabular}{|c|c|c|}
\hline \multirow{2}{*}{$\begin{array}{l}\text { Muhammadiyah's } \\
\text { young cadres }\end{array}$} & $\begin{array}{l}\text { Structural } \\
\text { response }\end{array}$ & $\begin{array}{l}\text { Having a view that many problems of intolerance and pluralism } \\
\text { in Indonesia tend to lead to the process of dehumanization } \\
\text { (degradation of the value of human rights) }\end{array}$ \\
\hline & $\begin{array}{l}\text { Cultural } \\
\text { response }\end{array}$ & $\begin{array}{l}\text { Moderate: Introducing the view of unity and ukhuwwah to } \\
\text { Muslims. Desiring an open, balanced and equitable dialogue } \\
\text { with exclusive Islamic groups. }\end{array}$ \\
\hline \multirow[b]{2}{*}{$\begin{array}{l}\text { Nahdlatul Ulama's } \\
\text { young cadres }\end{array}$} & $\begin{array}{l}\text { Structural } \\
\text { response }\end{array}$ & $\begin{array}{l}\text { Having an argument that many cases of intolerance are caused } \\
\text { by the role of irresponsible elite political influence. }\end{array}$ \\
\hline & $\begin{array}{l}\text { Cultural } \\
\text { response }\end{array}$ & $\begin{array}{l}\text { Moderate: Introducing the view of friendly Islam, polite Islam } \\
\text { and peaceful Islam in the interfaith community, religious } \\
\text { community, and mass organizations. }\end{array}$ \\
\hline
\end{tabular}

The researchers compare the understanding of young moderate cadres of Muhammadiyah and Nahdlatul Ulama with senior members in these organizations. Moreover, the researchers also contrast the results with last year's research regarding moderate organizations' responses to radical mass organizations. The last year's informants were middle-aged cadres who had long been involved in moderate mass organizations.

\section{Conclusion}

This study concludes that there are variations in patterns between young and old informants, both in Muhammadiyah and Nahdlatul Ulama. The young cadres of Muhammadiyah recognize that they are more likely to be more violent towards intolerant mass organizations compared to their seniors (old cadres). On the other hand, senior cadres such as Muhammadiyah Youth and Muhammadiyah themselves tend to be more composed in responding to the presence of radical organizations.

Senior cadres in Muhammadiyah organization tend to be more open-minded regarding radical and fundamental organizations and addresses their presence. It indicated by the absence of a sense 
of precariousness. The senior cadres do not consider the presence of radical and fundamental organizations as a threat to religious and national life, as long as it is in the corridor of diversity. On the other hand, Nahdlatul Ulama shows a different pattern. The organization's young informants reveal that their seniors tend to be harsher in responding to radical organizations and supporting mass organizations. This concern can be seen from every young informant of Nahdlatul Ulama in responding to radical and fundamental organizations, where reactionary actions and efforts are taken to disband Islamic discussions or studies that are considered threatening the integrity of the nation, including treason. The senior members often disbanded and deterred such discussions, either directly or indirectly.

\section{References}

Abdillah M (1999) Demokrasi Di Persimpangan Makna: Respons Intelektual Muslim Indonesia terhadap Konsep Demokrasi (1966-1993). Yogyakarta: Tiara Wacana.

Adhayanto O (2011) Khilafah dalam sistem pemerintahan Islam. Jurnal Ilmu Politik dan Ilmu Pemerintahan 1 (1).

Aminah S (2007) Politik media, demokrasi dan media politik. Masyarakat, Kebudayaan, dan Politik $19(3): 35-46$.

Ahnaf MI (2016) Tiga jalan Islam politik di Indonesia: Reformasi, refolusi, dan revolusi. Wawasan: Jurnal Ilmiah Agama dan Sosial Budaya 1 (2):127-140.

Amir ZA (2003) Peta Islam Politik Pasca-Soeharto. Jakarta: LP3ES

Anshori DS (2008) Hegemoni dan Dominasi Bahasa Pejabat dalam Media Massa Pasca Orde Baru: Analisis Wacana Kritis tentang Idiom Politik di Indonesia. Seminar dan Lokakarya Nasional. Bandung 30 Agustus 2008.

Aspinall E (2005) Elections and normalization of politics in Indonesia. South East Asia Research 13 (2).

Barton G (1997) Indonesia's Nurcholish Madjid and Abdurrahman Wahid as intellectual ulama: The meeting of Islamic traditionalism and modernism in neo-modernist thought. Islam and Christian-Muslim Relations 8 (3):323-350.

Barton G (2014) The gülen movement, Muhammadiyah and Nahdlatul Ulama: Progressive Islamic thought, religious philanthropy and civil society in Turkey and Indonesia. Islam and Christian-Muslim Relations 25 (3):287-301.

Biyanto (2009) Pluralism discourse: The views of young Muhammadiyah intellectuals. Journal of Indonesian Islam 3 (2).

Bollen KA (1990) litical democracy: Conceptual and measurement traps. Studies In Comparative International Development 25 (1):7-24.

Brenner S (2011) Private moralities in the public sphere: Democratization, Islam, and gender in Indonesia. American Anthropologist 113 (3):4780-490.

Bruinessen MV (2002) Genealogies of Islamic radicalism in post-Suharto Indonesia. South East Asia Research 10 (2):117-154.

Danim S (2002) Menjadi Peneliti Kualitatif. Bandung: Pustaka Setia.

Dewantara WA (2017) Diskursus Filsafat Pancasila Dewasa Ini. Yogyakarta: Kanisius.

Fish MS (2002) Islam and authoritarianism. World Politics 55 (1):4-37.

Freedman AL (2009) Civil Society, Moderate Islam, and Politics in Indonesia and Malaysia. Journal of Civil Society 5 (2):107-127.

Galston WA (1995) Two Concepts of Liberalism. Ethnics 10 (3):516-534.

Habermas J (2004) Religious tolerance-The pacemaker for cultural rights. Philosophy 79 (1).

Hadiz VR (2003) Reorganizing political power in Indonesia. The Pacific Review 16 (4):607.

Hadiz VR (2004) The rise of neo-third worldism? The Indonesian trajectory and consolidation of illiberal democracy. Third World Quarterly 25 (1):55-71. 
Hadiz VR (2018) The "floating" ummah in the fall of "Ahok" in Indonesia. TRaNS: Trans-Regional and -National Studies of Southeast Asia.

Haidar MA (1994) Nahdatul Ulama dan Islam di Indonesia: Pendekatan Fikih dalam Politik. Jakarta: PT Gramedia Pustaka Utama.

Hamdi AH (2017) Moving towards a Normalised Path: Political Islam in Contemporary Indonesia. Universitas Muhammadiyah Yogyakarta 4.

Hornby AS (1989) Oxford Advanced Leaners Dictionary of Current English. Oxford: Oxford University Press.

Jahroni JJ (2004) Gerakan Salafi Radikal di Indonesia. Jakarta: Rajawali Press.

Jung E (2014) Islamic organizations and electoral politics in Indonesia: The case of Muhammadiyah. South East Asia Research 22 (1):73-86.

Jurdi S (2010) Muhammadiyah dalam Dinamika Politik Indonesia 1966-2006. Yogyakarta: Pustaka Pelajar.

Kaelan (2005) Metode Penelitian Kualitatif Bidang Filsafat. Yogyakarta: Paradigma.

Khairazi F (2015) Implementasi demokrasi dan Hak Asasi Manusia di Indonesia. Jurnal Inovatif 8 (1).

Khan M (2003) Radical Islam, liberal Islam. Current History 102 (668).

Kurzman C (ed) (2003) Wacana Islam Liberal: Pemikiran Islam Kontemporer tentang Isu-Isu Global.

Lipset SM (1990) The centrality of political culture. Journal of Democracy 1 (4):80-83.

Lubis A (2009) Upaya meningkatkan partisipasi masyarakat dalam pembangunan. Jurnal Tabularasa PSS Unimed 6 (2):181-190.

Lym M (2005) Islamic Radicalism and Anti-Americanism in Indonesia: The Role of the Internet. Washington DC: East-WestCenter Washington.

Maksum A (2017) Discources on Islam and Democracy in Indonesia: A Study on the Intellectual Debate between Liberal Islam Network (JIL) and Hizbut Tahrir Indonesia (HTI). Journal of Indonesia Islam, Vol 11(02) Desember: 405-422.

Margono H (2011) KH. Hasyim Asy'ari dan Nahdlatul Ulama: Perkembangan awal dan kontemporer. Media Akademika 26 (3).

Matolino B (2009) A response to Eze's critique of Wiredu's consensual democracy. South African Journal of Philosophy 28 (1):34-42.

McGregor EK (2009) Confronting the past in contemporary Indonesia. Critical Asian Studies 41 (2):195-224.

Miller D (1992) Deliberative democracy and social choice. Political Studies 40 (1):54-67.

Morrison DG \& Stevenson HM (1972) Cultural pluralism, modernization, and conflict: An empirical analysis of sources of political instability in African Nations. Canadian Journal of Political Science 5 (01):82.

Muhtadi B (2013) Politik uang dan dinamika elektoral di Indonesia: Sebuah kajian awal interaksi antara "Party-ID" dan Patron-Klien. Jurnal Penelitian Politik 10 (1).

Mujani S \& Liddle RW (2004) Politics, Islam, and public opinion. Journal of Democracy 15 (1):109123.

Mujani S \&Liddle RW (2009) Muslim Indonesia's secular democracy. Asian Survey 49 (4):575-590.

Muqoyyidin AW (2013) Membangun kesadaran inklusif-multikultural untuk deradikalisasi Pendidikan Islam. Jurnal Pendidikan Islam 2 (1).

Mutaqin ZZ (2016) The strong state and Pancasila: Reflecting Human Rights in the Indonesian Democracy. Constitutional Review 2 (2).

Muttaqien A (2014) Kekerasan atas Nama Agama, Tindakan Fatal Vonis Minimal. [Accessed 10 June 2019]. https://referensi.elsam.or.id/2014/12/kekerasan-atas-nama-agama-tindakanfatal-vonis-minimal/. 
Nubowo A (2015) Islam dan Pancasila di era reformasi: Sebuah reorintasi aksi. Jurnal Keamanan Nasional 1 (1).

NurT (2018) Pemberdayaan Organisasi Kepemudaan dalam Meningkatkan Kesejahteraan Masyarakat (Studi Program AKUNU GP ANSOR LAMPUNGI). Thesis, UIN Raden Intan Lampung.

Pertiwi A (2015) Analisis Kriminologis terhadap Tindakan Main Hakim Sendiri oleh Ormas FPI (Front Pembela Islam) di Wilayah Hukum Kota Makassar. Thesis, Universitas Hasanuddin.

Poti J (2011) Demokratisasi media massa dalam prinsip kebebasan. Jurnal Ilmu Politik dan Ilmu Pemerintahan 1 (1).

Rachman BM (2001) Reorientasi Pembaharuan Islam. Jakarta: Paramadina.

Rachman BM (2010) Reorientasi Pembaruan Islam: Sekularisme, Liberalisme dan Pluralisme Paradigma Baru Islam Indonesia. Jakarta: Lembaga Studi Agama dan Filsafat (LSAF) dan Paramadina.

Ratnasari D (2010) Fundamentalisme Islam. Komunika 4 (1):40-57.

Rokhmad A (2012) Radikalisme Islam dan upaya deradikalisasi paham radikal. Walisongo 20 (1).

Roy O (1994) The Failure of Political Islam. Massachusetts: Hardvard University Press.

Saifullah I (2016) Sikap Toleransi dalam Menghadapi Perbedaan ideologi Keagamaan pada Aktivis IMM di Kota Yogyakarta". Thesis, Universitas Muhammadiyah Yogyakarta.

Sakai M \& Fauzia A (2013) Islamic orientations in contemporary Indonesia: Islamism on the rise?. Asian Ethnicity 15 (1):41-61.

Saraswati R (2012) Desain sistem pemerintahan presidensial yang efektif. Masalah-Masalah Hukum $41(1)$.

Sephard W (1987) Fundamentalism Christian and Islamic. Religion 17:355-378.

Schumpeter JA (1947) Capitalism, Socialism, and Democracy. New York: Harper.

Schmitter P \& Karl TL (1991) What democracy is... and is not. Journal of Democracy 2 (3):75-88.

Silberman I, Higgins ET, \& Dweck CS (2005) Religion and world change: Violence and terrorism versus peace. Journal of Social Issues 61 (4):761-784.

Sopyan Y (2015) Menyoal kebebasan beragama dan penodaan agama di Indonesia. Jurnal Cita Hukum 2 (2):95-212.

Sparringa D (2006) Daniel Sparringa dan Ignas Kleden, Konsep Demokrasi, Modul 00. Jakarta: Komunitas Indonesia untuk Demokrasi.

Stace WT (1950) What Are our Values?: Values in General, Democratic Values and Why Do We Fail. Lincon: The University of Nebraska.

Sulistyo H (2002) Electoral Politics in Indonesia: A Hard Way to Democracy. Singapore: FES. Susilowati I, Yunus NR, \& Sholeh M (2019) Politics of identity on great 212's reunion. Dauliyah 4 (1). Ummah SC (2012) Akar radikalisme Islam di Indonesia. Humanika (12)

Volpi F (2004) Pseudo-democracy in the muslimworld. Third World Quarterly 25 (6):1.061-1.078.

Wahid A \& Taylor H (2008) A tradition of tolerance in Indonesia offers hope. Foreign Service Journal (April 2008).

Wardani NAK (2019) Peran pimpinan cabang gerakan pemuda ansor sidoarjo dalam meningkatkan nasionalisme untuk menangkal radikalisme. Kajian Moral dan Kewarganegaraan 7 (1):301315.

Woodward MR (2001) Indonesia, Islam, and the prospect for democracy. SAIS Review 2 (2):29-3.

Zain ZFS (2007) Pandangan Muhammadiyah terhadap Pluralitas Agama. Thesis, Universitas Muhammadiyah Surakarta.

Zuhdi MH (2010) Fundamentalisme dan upaya deradikalisasi pemaknaan Al-Qur'an dan Hadis. Religia 13 (1):81-102. 